\title{
The Standard Auditor's Report: Preparer, User, And Student Reactions To The PCAOB Concept Release
}

Don E. Giacomino, CPA, Marquette University, USA

Michael D. Akers, CPA, CMA, CFE, CIA, Marquette University, USA

\begin{abstract}
Concerns about the usefulness of the Standard Audit Report (SAR) have been expressed by investors and other users of corporate financial statement for several decades. During 2011 the Public Company Accounting Oversight Board (PCAOB) reacted to those concerns by issuing Concept Release on Possible Revisions to the PCAOB Standards Related to PCAOB Standards ("Release"). This article provides a description of the SAR, a short history (timetable) of the pressures (surveys) to improve the SAR and events that have led to the eventual Release by the $P C A O B$. Feedback (comment letters and surveys) from professionals and professional organizations regarding the "Release" are examined and discussed. Accounting and finance majors, future preparers and users of the financial statements, were surveyed to determine both their reactions to the PCAOB's $S A R$ and whether their reactions were different than practitioners. This article concludes with an analysis of the results and implications for audit practice and education.
\end{abstract}

Keywords: Usefulness of Standard Audit Report (SAR); Public Company Accounting Oversight Board

\section{INTRODUCTION}

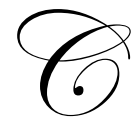

oncerns about the usefulness of the Standard Audit Report (SAR) have been expressed by investors and other users of corporate financial statement for several decades. Recently (June 21, 2011), the Public Company Accounting Oversight Board (PCAOB) has reacted to those concerns by issuing Concept Release on Possible Revisions to the PCAOB Standards Related to PCAOB Standards ("Release"). Several groups and individuals representing investors and other users of the SAR have reacted to recommendations contained in the Release. This article focuses on the usefulness of the SAR. We begin by describing the SAR, and then we provide a short history (timetable) of the pressures (surveys) to improve the SAR and events that have led to the eventual Release by the PCAOB. Next, we summarize feedback (comment letters and surveys) from professionals and professional organizations. Then, we describe our survey of accounting and finance majors regarding their responses to a PCAOB. This article concludes with an analysis of the results and implications for audit practice and education.

\section{STANDARD AUDIT REPORT (SAR)}

There have been few changes in the standard audit report during the past 60 years. Prior to 1988 the audit report had not changed since 1948. In 1988, Statement on Auditing Standards (SAS) 58, Reports on Audited Financial Statements made significant changes in the audit report. It is interesting to note that the profession had tried to make changes to the audit report since 1965. SAS 58 incorporated the following changes: 3-paragraph format (introductory, scope and opinion) instead of two, added "independent" to the title, changed "examined" to "audited" in the introductory paragraph, added the wording that "these financial statements are the responsibility of management" in the introductory paragraph, added this specific statement in the introductory paragraph regarding the auditor's responsibilities-"our responsibility is to express an opinion on these financial statements based on our 
audit", indicated in the scope paragraph that auditing standards require that an audit be "planned and performed to obtain reasonable assurance about whether the financial statements are free of material misstatement", added two sentences to the scope paragraph describing audit procedures, added a statement to the end of the scope paragraph"we believe our audit provides a reasonable basis for our opinion", added to the opinion paragraph "in all material respects", deleted the reference to the consistent application of generally accepted accounting principles and replaced the "subject to" wording with an unqualified opinion and explanatory paragraph. These changes were intended to make the audit report more useful by defining an audit and more effectively communicating the responsibilities of management and the auditor with the hope that SASs (53-61) would help reduce the expectation gap. Since 1988 minor changes (reference to PCAOB standards and auditor's opinion on the effectiveness of internal control over financial reporting) have been made to the audit report. Interestingly, the current PCAOB proposals once again focus on the usefulness of audit report and as well as the responsibilities of management and the auditor. As Joseph Carcello $(2012$, p. 22) states "The only outcome of the audit process that is observable to the investor is the auditor's report - and in most cases an unmodified, or clean, report is issued." Many financial statement users and user groups have suggested ways to improve the SAR. Next, this article identifies the pressures for change and specific suggested recommendations.

\section{PRESSURES FOR IMPROVEMENT OF THE SAR}

Concerns about the usefulness of the SAR are not new. In his speech of March 22, 2011, Steven B. Harris, (PCAOB Board Member) at the PCAOB Open Board Meeting in Washington, DC, commends the PCAOB for dealing with the issue. He indicates that as early as 1978, during its study of the SAR, the Cohen Commission referred to the fact that an audit involves "scores of auditors and tens of thousands of hours of work... Nevertheless, the auditor's standard report compresses that considerable expenditure of skilled effort into relatively few words and paragraphs (http://pcaobus.org/News?Speech/Pages/03222011 HarrisStatement.aspx)." Even the auditors have expressed concerns about the usefulness of the SAR. Harris also stated that, in a 2006 report, CEO's of the largest public accounting firms acknowledged that:

... users of financial information may demand ... to receive more finely nuanced opinions from auditors about the degree of a company's compliance with a given set of standards, or the relative conservatism of judgments compared to peer groups. ... Investors even may want the auditor's views about the overall health and future prospects of the companies they audit.

In 2008, the Treasury Department's Advisory Committee on the Audit Profession urged the PCAOB to consider setting a standard that deals with improving the SAR. Outside the United States, The European Commission (in a Green Paper) has called for improving communication between auditors and investors; and the UK's Financial Reporting Council has made new reporting proposals.

Also, in 2008, the CFA Institute Member Poll on the Independent Auditor found that 94\% of respondents would like to see additional information in the auditor's report and $80 \%$ responded that the "independent external auditor's report (should) provide specific information about how the auditors reach their unqualified opinion" (http://www.cfainstitute.org/survey/independent_auditors_report_poll_results_march_2008.pdf)

The CFA Institute conducted a more recent survey in March of 2011 (http://www.cfainstitute.org /survey/usefulness_of_independent_auditors_report_survey_results_march_2011.pdf) That online survey, completed by 106 members, found that $58 \%$ of their responding members think the SAR needs to provide more specific information about how the auditors reach their opinion, although $30 \%$ do not think the SAR needs to provide more specific information. Respondents had these reasons (among a larger list) for favoring more disclosure and keeping the SAR in its current form: 


\section{Reasons for Differing Positions on Requiring More Disclosures in the SAR}

\section{Favor More Disclosure in SAR}

The current SAR is boilerplate.

SAR is very generic.

SAR is formulaic, hides poor audit methods

Explain how the opinion was reached

SAR shows little reasoning and analysis.

Need deeper insight on how opinion formed.

Identify key issues in the SAR.

\section{Keep SAR in Current Form}

SAR is sufficient for educated investors.

Audit procedures shouldn't have to be explained in SAR.

Degree of detail required would be too long.

Confidentiality and relationship reasons would water down value of the added information in the SAR.

The opinion is already self-explanatory.

Users don't have to know every detail.

I can't imagine how this would look.

In 2009, the PCAOB (http://pcaobus.org/News/Speech/Pages/07282009 StatementGoelzerEPS.aspx) issued a concept release on engagement partner signature. This was in reaction to a survey by the PCAOB Investment Advisory Group (http://www.nasba.org/files/2011/04/PCAOB-Report-Goelzer.pdf) which found that $44 \%$ of investors thought the engagement partner should personally sign the audit report. An alternative to the signature may be identification of the engagement partner in the audit report.

On March 31, 2011, the Center for Audit Quality wrote an alert "The Auditor's Reporting Model" on its website (www.thecaq.org). The alert is a high level summary of the PCAOB's March 24, 2011 SAB meeting and the March 22, 2011 PCAOB open Board meeting. Most of the alert consisted of a presentation by Jennifer Rand, PCAOB Deputy Chief Auditor, at the March $22^{\text {nd }}$ meeting. Ms. Rand reported that across the board, all constituent groups believed that change to the existing auditor's reporting model was needed. Ms. Rand indicated that investors expressed interest in:

- $\quad$ information about what the audit did (risks identified by the auditor, auditor's materiality assessments, engagement data such as hours spent on the significant areas, auditor independence and issues discussed with the audit committee);

- the auditor's views on the financial statements and findings, such as auditor's views on management's estimates, judgments and areas of high risk, difficult or contentious issues and auditor's views on accounting policies;

- added clarification by the auditor regarding the meaning of "reasonable assurance", the auditor's responsibility for detecting fraud, and the auditor's responsibility relative to disclosures in the financial statements;

- $\quad$ clarification of the auditor's responsibility (or enhanced responsibility) for information outside the financial statements (e.g., MD\&A, non-GAAP information, earnings releases); and

- $\quad$ information on key issues discussed between the auditor and the audit committee.

Rand also summarized feedback from preparer's, audit committee members and auditors. Their common themes are reported later in this article.

\section{THE CONCEPT RELEASE ("RELEASE")}

In reaction to these recent, increasing concerns about the usefulness of the SAR, the PCAOB (June 21, 2011) has issued Concept Release on Possible Revisions to the PCAOB Standards Related to Reports on Audited Statement and Related Amendments to PCAOB Standards (hereafter referred to as "Release") 
(http://pcaobus.org/News/Releases/Pages/06212011_OpenBoardMeeting.aspx). Following is the objective statement for the Release:

The objective of this concept release is to discuss several alternatives for changing the auditor's reporting model that could increase its transparency and relevance to financial statement users, while not compromising audit quality. To that end, these alternatives include (1) a supplement to the auditor's report in which the auditor would be required to provide additional information about the audit and the company's financial statements (an "Auditor's Discussion and Analysis"), (2) required and expanded use of emphasis paragraphs in the auditor's report, (3) auditor reporting on information outside the financial statements, and (4) clarification of certain language in the auditor's report. These alternatives are not mutually exclusive. A revised auditor's report could include one or a combination of these alternatives or elements of these alternatives. Additionally, there may be other alternatives to consider that this concept release does not present.

As stated in the Release, “... the alternatives proposed are focused primarily on enhancing communication to investors through improving the content of the auditor's report rather than on changing the fundamental role of the auditor..." The Release does recognize that requirements for new information in the audit report, new auditing requirements and coordination with the SEC would be necessary and certain alternatives may increase the scope of audit procedures and, consequently new audit standards.

\section{PROFESSIONAL REACTIONS TO THE RELEASE}

After issuing the Release, the PCAOB held a roundtable meeting on September 15, 2011 with 32 participants and two observers from the SEC and FASB. The deadline for comment letters was September 30, 2011. Up to the date of the roundtable meeting, 152 comment letters were received. The PCAOB Standard Advisory Group Meeting on November 10, 2011 (http://pcaobus.org/Rules/Rulemaking/Docket034/11102011_SAG_ Transcript.pdf) provided the following breakdown for sources of the letters:

\section{Comment Letter Writers}

Preparers, internal auditors and preparer association

Accounting firms and associations of accountants

Investors (includes investor associations, pension managers, Analysts, large investment

companies and advisers)

Academics

Other regulators and standard setters

Board members, including audit committee members, and their associations

Other individuals and organizations

Total

\begin{tabular}{r} 
\# of letters \\
\hline 70 \\
35 \\
16 \\
7 \\
7 \\
6 \\
$\underline{11}$ \\
$\underline{\underline{152}}$
\end{tabular}

Following is a summary of the reactions from a variety of groups responding to the issues covered in the Release. The overall response from commenters and roundtable participants is to retain the pass/fail opinion. Although there is general support for changing the SAR, the range of support varies by type of commenter.

- $\quad$ All groups support clarification of language within the SAR, but preparers, internal auditors and preparer associations don't believe it is necessary. This group opposes the "AD \& A" concept and the "required and expanded emphasis paragraph" and they believe that costs outweigh the benefits for assurance on information outside the financial statements.

- $\quad$ Board members, including audit committee members and their associations also oppose "AD \& A" type reporting, but they show some support for assurance on information outside the financial statements. The group has mixed views regarding the proposal for required and expanded emphasis paragraph.

- Accounting firms and associations of accountants oppose "AD \& A" type reporting. However, large and regional accounting firms have opinions that differ from those of the small accounting firms. Small accounting firms generally do not support additional reporting; while the large and regional firms generally support objective and factual "required and expanded emphasis" paragraph type report and the attestation on the critical accounting estimates section of the Management Discussion and Analysis. 
- Commenters and roundtable participants suggested that other regulators and standard setters (FASB/SEC, IASB) work toward a coordinated solution. They also favor additional reporting on audit committee communication (with auditor).

- $\quad$ Some frequently mentioned concerns about changing the auditor's reporting model are: adverse effect on audit committee's governance role; impairment of the three-way communication between auditor, audit committee and management; the risk of additional boiler-plate language; increased costs; loss of confidentiality of company information; the potential increase in legal liability of audit firms; the possible adverse effect on auditor independence; and minimal improvement in audit quality.

\section{THE PCAOB INVESTOR ADVISORY GROUP SURVEY}

At the July 15, 2010 meeting, the PCAOB Investor Advisory Group (http://pcaobus.org/News/Events/Docu ments/07152010_SAGMeeting/Auditors_Reporting_Model.pdf) discussed the auditor's report and the Office of the Chief Auditor conducted focus group with auditors, audit committee members, preparers and investors regarding changes to the SAR. In addition, a task force of the PCAOB Investor Advisory Group (IAG) conducted a survey of investors to obtain their view on the changes. Joseph Carcello (2012), a committee member, reported the survey results in the January 2012 issue of The CPA Journal. The questionnaire focused on potential changes to the information the auditor communicates and the manner in which the auditor communicates information (p. 23). The survey asked respondents to answer a question on the usefulness of the current SAR and asked them to indicate how they use the SAR. In addition, the survey asked questions regarding changes to the substance of information in the audit report and the form of the report. One of the questions asks the respondent to indicate (using a 5-point Likert scale, $1=$ strongly disagree and $5=$ strongly agree with proposed change) whether they agree that the current SAR provides the SAR currently provides useful information. Only $23 \%$ agreed. When asked how they use the SAR, $18 \%$ of the respondents said the SAR was of no use to them at all and $73 \%$ said they simply skim the report looking for departures from the standard unqualified report (p.24 of Carcello article). The most desired changes to the SAR were these disclosures: (1) discuss assessments of estimates and judgments by management, (2) disclose more information on areas of high financial and audit risk and how the auditor addressed those risks, (3) discuss unusual transactions, restatements and other significant changes, and (4) discuss the quality of the issuer's accounting policies and practices. Table 1 shows the mean responses and rankings for each of 14 disclosures that relate to the issues in the Release. More discussion of these disclosures follows in the next section where results of the PCAOB survey are compared with our survey of accounting majors and accounting and finance double majors.

\section{SURVEY OF ACCOUNTING AND DOUBLE MAJORS IN ACCOUNTING AND FINANCE}

To obtain the opinions of future preparers and users of the SAR, we conducted a survey of undergraduate and graduate accounting and finance majors at a private university. We used a survey form (Exhibit 1) that covers the same disclosure issues that the PCAOB used for its survey of business professionals and professional associations. On the instructions page, respondents are provided with a sample of an SAR under current reporting standards and they are asked to give their opinion on the usefulness of the audit report. The back side of the survey form contains questions that relate to the specific alternatives discussed in the Release. Students were asked to check their major (accounting, finance or other).

During the first week of February of 2012, we distributed the survey to 79 business students enrolled in auditing (one section) and financial statement analysis (two sections) classes at a private, mid-western university. Of the 79 respondents, 47 are accounting majors, 20 are double majors (accounting/finance), four are finance majors and eight did not indicate their major. For the three sections, instructors presented a very brief summary of the contents of the audit report and the purpose of the survey. Participation was voluntary and anonymous.

While the student respondents (3.75) agree more so than the professionals (2.6) that the audit report currently provides valuable information, the findings aren't strong. As discussed below, there were other items where the students had stronger support than they had for the usefulness of the audit report. Since students have less experience with using audit reports in making business decisions and approximately half of the respondents were in an auditing course, we aren't surprised the students had stronger support, as compared to the professionals, for the value of the information in the audit report. 
Table 1 shows the mean values for each of the audit report disclosures and the ranking based on mean values. The ranking differences are greater than four ranks for only four of the fourteen disclosures, with the greatest differences (eight ranks) on including the audit partner signature in the audit report and disclosure of audit adjustments. The professionals, which include auditors and accounting associations, are less inclined to favor these two requirements which focus more on items that appear to be more objective than some of the other proposed items. The next greatest difference (seven ranks) is for significant estimates and judgments, where the professionals (PCAOB survey) rate this disclosure highest among the 14 disclosures. Professionals also rate disclosure of sensitivity analysis five ranks higher than the students. Significant estimates/judgments and sensitivity analysis both require more professional judgment and subjectivity in evaluating the financial statements and footnotes. Accordingly, we aren't surprised that professionals would place more importance on these items than students as the professionals have more experience using such information.

Table 1

PCAOB (2011) and Student Survey (2012)

Mean Response $(1=$ not necessary, $3=$ neutral, $5=$ necessary $)$

\begin{tabular}{|c|c|c|c|c|}
\hline \multirow[b]{2}{*}{ Nature of Issue (Disclose) } & \multicolumn{2}{|c|}{ PCAOB Survey } & \multicolumn{2}{|c|}{ Student Survey } \\
\hline & Mean & Rank & Mean & Rank \\
\hline Significant Estimates and Judgments & 3.96 & 1 & 3.39 & 8 \\
\hline Risk & 3.96 & 2 & 3.85 & 3 \\
\hline Unusual Transactions, restatements \& other changes & 3.80 & 3 & 3.60 & 4 \\
\hline Quality of Accounting Policies and Practices & 3.71 & 4 & 4.08 & 2 \\
\hline Sensitivity Analysis & 3.56 & 5 & 3.15 & 10 \\
\hline Materiality & 3.50 & 6 & 3.52 & 6 \\
\hline Information communicated to audit committee & 3.47 & 7 & 2.89 & 11 \\
\hline Issues in summary audit memo & 3.46 & 8 & 3.32 & 9 \\
\hline Audit partner signature on report & 3.28 & 9 & 4.25 & 1 \\
\hline Fraud roles and responsibilities of auditor & 3.20 & 10 & 3.44 & 7 \\
\hline Replace binary report with multiple levels & 3.04 & 11 & 2.65 & 13 \\
\hline Grade aggressiveness vs. conservatism & 2.94 & 12 & 2.75 & 12 \\
\hline Audit adjustments & 2.92 & 13 & 3.53 & 5 \\
\hline Disclose audit hours & 2.51 & 14 & 2.05 & 14 \\
\hline
\end{tabular}

Table 2 provides the percentage of respondents in each survey who favor (respond with a " 4 " or " 5 ") each of the disclosures. Four seven (half) of the disclosures, less than half of the professionals rate the disclosure as necessary. The disclosure with the smallest percentage (21\%) is disclosure of audit hours. Next lowest are quality of accounting policies and practices and disclosure of audit adjustments. Understandably, the auditors and audit associations would be less inclined to favor making these judgment calls on audit policies and disclosing what might be a large number of audit adjustments. However, we can see why the investors and other users of financial statements would like to see those disclosures.

As was found in the PCAOB survey, for seven (half) of the 14 disclosure issues, less than $50 \%$ of the students are in favor (responded with a "4" or a " 5 ") of the disclosure. However, we see some large differences between professionals (PCAOB survey) and students on many of the disclosures. For nine of the 14 disclosure issues, the percentage gaps between professionals exceed ten percentage points. The largest gap between professionals and students is for the disclosure of the quality of accounting policies and practices. Students were much more in favor (75\% vs. 39\%) of this disclosure than were the professionals (which included auditors and accounting associations). This disclosure has the potential for expanding the auditor's legal liability for the audit; thus, we can understand why many students, with no liability risk, would be more in favor of this qualitative assessment of a company's accounting policies and practices. The next largest gap is for inclusion of the audit partner's signature on the SAR. Again, a much larger percentage of students (72\% vs. 44\%) favor this inclusion. Perhaps, the practitioners fear expansion of the auditor's legal liability? Another large difference $(27 \%)$ exists for disclosure of significant estimates and judgments. However, to our surprise, the professionals were more in favor (79\% vs. 52\%) than were the students. We had expected that some of the professionals (auditors and accounting associations) would be concerned about the potential for this disclosure expanding the auditor's legal liability. 
Table 2

PCAOB (2011) and Students (2012)

Percent in Favor of Disclosure

(Responded with a "4" or "5")

\begin{tabular}{lcc}
\hline Nature of Issue $\quad$ (Disclose) & $\begin{array}{c}\text { PCAOB Survey } \\
\text { \% Necessary }\end{array}$ & $\begin{array}{c}\text { Student Survey } \\
\text { \% Necessary }\end{array}$ \\
\hline Significant Estimates and Judgments & $79 \%$ & $52 \%$ \\
Risk & $77 \%$ & $75 \%$ \\
Unusual Transactions, restatements \& other changes & $67 \%$ & $59 \%$ \\
Quality of Accounting Policies and Practices & $39 \%$ & $75 \%$ \\
Sensitivity Analysis & $65 \%$ & $42 \%$ \\
Materiality & $56 \%$ & $61 \%$ \\
Information communicated to audit committee & $56 \%$ & $30 \%$ \\
Issues in summary audit memo & $54 \%$ & $44 \%$ \\
Audit partner signature on report & $44 \%$ & $72 \%$ \\
Fraud roles and responsibilities of auditor & $43 \%$ & $47 \%$ \\
Replace binary report with multiple levels & $45 \%$ & $22 \%$ \\
Grade aggressiveness vs. conservatism & $42 \%$ & $27 \%$ \\
Audit adjustments & $39 \%$ & $56 \%$ \\
Disclose audit hours & $21 \%$ & $8 \%$
\end{tabular}

For disclosure of information communicated from the auditor to the audit committee, the professionals were much more in favor $(56 \%$ vs. $30 \%)$. In part, this might be caused by an unclear understanding by the students of the relationship between the auditor and the audit committee. Greater percentages of professionals were also in favor of disclosure of sensitivity analysis (65\% for professionals vs. $42 \%$ for students) and for replacing the binary audit report with multiple levels of assurance ( $45 \%$ for professionals vs. $22 \%$ for students. Some of the large differences where the professionals are more in favor of specific disclosures might be explained by the fact that the respondents to the PCAOB study consist of many users of the audit report; while the student group is probably dominated by future preparers and auditors.

We find small (less than 10\%) differences between professionals and students regarding their views on the necessity of five disclosure issues in the audit report:

- $\quad$ Both groups highly favor (79\% professionals and 75\% students) disclosure of risk.

- $\quad$ Both groups favor disclosure of unusual transactions, restatements and other changes $(67 \%$ professionals and $59 \%$ students).

- $\quad$ Both groups favor (56\% professionals and $61 \%$ students) disclosure of materiality.

- Less than 50\% (43\% professionals and $47 \%$ students) of the respondents favor the disclosure of fraud roles and responsibilities of the auditor.

Finally, the disclosure least favored by both groups is the disclosure of audit hours. Only $21 \%$ of the professionals are in favor, while even fewer $(8 \%)$ of the students favor this disclosure.

\section{LIMITATIONS AND CONTRIBUTIONS}

The use of the students in this study creates three specific limitations in the data collected. First, the sample was not chosen at random. Second, all respondents come from one university, a mid-western private institution with approximately 11,500 students. Third, a self-reporting bias might exist as not all students completed the survey. The use of students is also a contribution as input from students is rarely solicited in the development of new auditing standards. Student input wasn't used by the profession in the development of SAS 58. 


\section{SUMMARY AND IMPLICATIONS FOR PRACTICE AND EDUCATION}

The accounting profession faces several challenges related to the alternatives discussed in the Release. Although preparers, auditors and users of financial statements see a need for improvement of the standard auditor's report, feedback in the form of comment letters and surveys show some disagreements on specific recommendations for improving the SAR. Understandably, auditors have concerns about the potential for increasing the auditor's liability, the possible loss of confidentiality, the possible adverse effect on independence and the audit committee's governance role. In addition, the proposed changes to the report must be considered in light of comparing the increased audit work and cost with the expected benefit of increased disclosures in the audit report. Of the four alternatives in the Release, financial statement preparers and auditors agree only on the need for clarifying language (e.g., the meaning of "reasonable assurance"), in the audit report.

Undergraduate (seniors) and graduate accounting and finance majors will soon be preparing and/or using financial statements and the related audit reports. While students use financial statements and audit reports in their courses, they don't have the same degree of experience as practicing professionals in preparing or using the statements and the audit report. Their feedback however, is useful for determining the degree to which we can expect understanding of possible new audit report requirements and compliance with those requirements. Students' input is also useful because they aren't biased by their professional experiences and therefore offer a fresh viewpoint on these proposals. Despite the difference in professional experience, we believe the similarities in responses (10 of 14 items) is valuable input for the PCAOB in evaluating which proposals should be adopted or eliminated. Both the findings of the PCAOB and our survey suggests some indifference to the PCAOB proposals as none of the average responses were 1 (strongly disagree or not necessary) and only two responses (students only) exceeded 4 (strongly agree or necessary).

The PCAOB's proposed changes to the auditor's reporting model are scheduled to be issued for public comment in quarter three of 2012 with adoption of the final standard or a re-propose standard for public comment in quarter two of 2013 (http://pcaobus.org/Standards/Documents/201203 standard_setting agenda.pdf). If these goals are met, the PCAOB will have been able to develop, approve and adopt changes to the auditor's report in considerably less time than it took the profession (20 years) to adopt SAS 58. When such changes are adopted accounting research will be necessary to determine if these changes have enhanced the usefulness of the audit report, thereby reducing the expectation gap, or if such changes have resulted in additional, boilerplate, meaningless wording that will only increase the length of an annual report. Accounting educators will have further opportunities to discuss and educate future preparers and users of the financial statements as to how regulation and political pressures impact the development and implementation of auditing standards.

\section{AUTHOR INFORMATION}

Dr. Don E. Giacomino, CPA is Professor of Accounting and the Donald and Beverly Flynn Chair Holder at Marquette University. He earned a DBA from the University of Kentucky and the MBA from the University of Montana. Giacomino has published a Management Accounting text and over 60 refereed articles in academic and professional journals, including Advances in Accounting, Journal of College Teaching and Learning, Journal of Accountancy, the CPA Journal, Issues in Accounting Education, International Business and Economics Research Journal and Journal of Managerial Issues. E-mail: don.giacomino@marquette.edu

Dr. Michael D. Akers, CPA, CIA, CMA, CFE, CBM is the Charles T. Horngren Professor of Accounting and Chair, Department of Accounting. He earned his doctoral degree at the University of Mississippi and his MBA at the University of Louisville. In addition to serving on the editorial advisory board of two journals, he has authored more than 60 articles in academic and professional journals. He currently serves on the Audit Committee and Board of Directors of two publicly traded companies and one not-for profit. E-mail: michael.akers@marquette.edu. Corresponding author. 


\section{REFERENCES}

1. Carcello, Joseph C. "What Do Investors Want from the Standard Audit Report," The CPA Journal. January, 2012. pp. 22-28.

2. http://www.cfainstitute.org/survey/independent_auditors_report_poll_results_march_2008.pdf

3. http://www.cfainstitute.org/survey/usefulness_of_independent_auditors_report_survey_results_march_201 1.pdf

4. $\quad$ http://www.nasba.org/files/2011/04/PCAOB-Report-Goelzer.pdf

5. Public Company Accounting Oversight Board. PCAOB Release No. 2011-003. June 21, 2011.

6. Public Company Accounting Oversight Board. http://pcaobus.org/News?Speech/Pages/03222011HarrisStatement.aspx

7. Public Company Accounting Oversight Board. http://pcaobus.org/Standards/Documents/201203_standard_setting_agenda.pdf

8. Public Company Accounting Oversight Board http://pcaobus.org/News/Speech/Pages/07282009_StatementGoelzerEPS.aspx

9. Public Company Accounting Oversight Board. http://pcaobus.org/News/Events/Documents/07152010_SAGMeeting/Auditors_Reporting_Model.pdf

10. Public Company Accounting Oversight Board Standard Advisory Group Meeting. http://pcaobus.org/Rules/Rulemaking/Docket034/11102011_SAG_Transcript.pdf, November 10, 2011. 


\section{EXHIBIT 1}

\section{Student Survey: Audit Report}

This survey asks for your opinion regarding the information that you believe should be included in the standard audit report (SAR). A sample of an SAR is shown below. First, please circle the number that indicates your opinion (scale is $1-5,1$ - strongly disagree and $5=$ strongly agree), then complete the questions on the other side of this form.

\begin{tabular}{|c|c|c|c|c|}
\hline 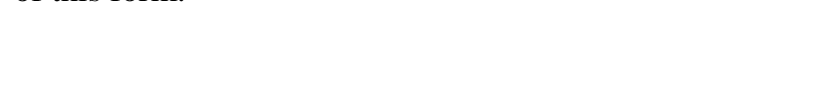 & $\begin{array}{l}\text { Strongly } \\
\text { Disagree }\end{array}$ & & & $\begin{array}{l}\text { Strongly } \\
\text { Agree }\end{array}$ \\
\hline Audit report currently provides valuable information & 2 & 3 & 4 & 5 \\
\hline
\end{tabular}

\section{Sample Audit Report for a publicly traded company}

To the Board of Directors and Shareholders ABC Company

Address

We have audited the accompanying balance sheets of ABC Company as of December 31, 2010, 2011 and 2012, and the related statements of income, retained earnings, and cash flows for the years then ended. These financial statements are the responsibility of the Company's management. Our responsibility is to express an opinion on these financial statements based on our audits.

We conducted our audit in accordance with the standards of the Public Company Accounting Oversight Board (United States). Those standards require that we plan and perform the audit to obtain reasonable assurance about whether the financial statements are free of material misstatement. An audit includes examining, on test basis, evidence supporting the amounts and disclosures in the financial statements. An audit also includes assessing the accounting principles used and significant estimates made by management, as well as evaluating the overall financial statement presentation. We believe that our audits provide a reasonable basis for our opinion.

In our opinion, the financial statements referred to above present fairly, in all material respects, the financial position of ABC Company as of December 31, 2010, 2011 and 2012, and the results of its operations and its cash flows for the years then ended in conformity with accounting principles generally accepted in the United States of America.

(Signature)

(Date) 


\section{EXHIBIT 1 (continued) STUDENT SURVEY: AUDIT REPORT}

Please rate the following items in terms of their necessity in the independent auditor's report.

1. Materiality disclosure $\quad \frac{\text { Not Necessary }}{1} 2^{\frac{3}{1}} \quad 4 \quad \frac{4}{5}$

Disclose specific quantitative and qualitative materiality thresholds.

$\begin{array}{lllllll}\text { 2. Risk disclosure } & 1 & 2 & 3 & 4 & 5\end{array}$

Disclose the areas that pose the greatest $F / S$ and audit risk.

3. Unusual transactions, restatements, and other changes $\quad \begin{array}{lllllllll} & 1 & 2 & 3 & 4 & 5\end{array}$

$\begin{array}{lllllll}\text { 4. Audit adjustments } & 1 & 2 & 3 & 4 & 5\end{array}$

Disclose adjustments to statements that were required by the auditor.

5. Grade: aggressiveness or conservatism $\quad \begin{array}{llllll}1 & 2 & 3 & 4 & 4\end{array}$ Auditor grades (1-10 scale) client's aggressiveness or conservatism of company's practices (e.g., revenue recognition earlier vs. later).

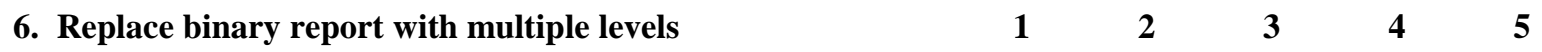

Use multiple levels of decision regarding the financial statements instead of current binary ("fair or "not fair") type of report.

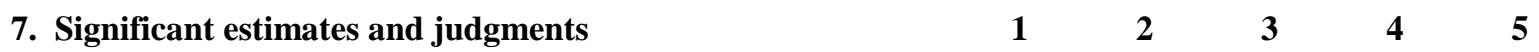

Discuss significant estimates made by management and the auditor's assessment of their accuracy.

$\begin{array}{lllllll}\text { 8. Sensitivity analyses } & 1 & 2 & 3 & 4 & 5\end{array}$

Disclose results of sensitivity analyses in significant areas of judgment (e.g., sensitivity of fair value of debt instrument to changes in credit standing of issuer).

9. Quality of accounting policies and practices

$\begin{array}{llllll}1 & 2 & 3 & 4 & 5\end{array}$

10. Discuss issues in summary audit memorandum $\quad \begin{array}{llllll} & 1 & 2 & 3 & 4 & 5\end{array}$ Include audit memo that discusses major issues encountered during the audit (e.g., audit procedures employed and evidence gathered, and how the issues were resolved by the engagement team.

11. Disclose audit hours

$\begin{array}{lllll}1 & 2 & 3 & 4 & 5\end{array}$

12. Discuss fraud roles and responsibilities of auditor.

$\begin{array}{llllll}1 & 2 & 3 & 4 & 5\end{array}$

13. Disclose information communicated to audit committee.

$\begin{array}{llllll}1 & 2 & 3 & 4 & 5\end{array}$

14. Audit partner signature on the audit report.

$\begin{array}{lllll}1 & 2 & 3 & 4 & 5\end{array}$


NOTES 